\title{
Aristotelian Dialectic, Medieval Jadal, and Medieval Scholastic Disputation
}

\author{
Mohammad Syifa Amin Widigdo
}

\begin{abstract}
This article argues that medieval Christian and Muslim scholarship employed Greek dialectic to differing purposes. Greek dialectic aims to defeat an opponent by exposing logical contradictions; Christian scholarship claims to use the dialectic to search for the truth in a pedagogical setting; and Muslim scholarship employs it to arrive at the truth with a degree of certainty. As a result, this article further argues, Greek dialectic in Christian and Muslim contexts undergoes some modifications. In the Christian context, dialectic serves a didactical purpose, which is to find the truth that resides in the mind of the teacher. In the Islamic context, Greek dialectic is employed to find epistemological $\left(q a t^{c} \vec{\imath}\right)$ or psychological (ghalabat al-zann) certainty in religious knowledge.
\end{abstract}

Debate, disputation, and argumentation are of course as old as humanity; each culture and civilization has its own argumentative tradition that employs certain rules and rhetorical expressions and serves its various purposes. Although medieval Christian and Muslim traditions had their own

Mohammad Syifa A. Widigdo completed his degree in the Department of Religious Studies, Indiana University, Bloomington, with a dissertation on Imam al-Haramayn al-Juwaynīs theory of jadal (dialectic) and its relation to Sunnī orthodoxy formation in medieval Islam. Currently he is a faculty member in the Magister Program of Islamic Studies at Universitas Muhammadiyah Yogyakarta (UMY), Indonesia.

The author would like to thank Dr. R. Kevin Jaques (Indiana University Bloomington) and Dr. Carrie E. Swanson (The University of Iowa) for their feedback on the early draft of this article. He would further like to thank the Department of Religious Studies of Indiana University, Bloomington, and IIIT for the support and fellowship during his research and writing. 
history of argumentative practices, their encounter with Greek dialectical scholarship provided them each a new dimension and direction. Yet analysis of the Muslim and Christian reception of Greek dialectic and of how it shapes their scholarship has never been comprehensively conducted. The existing literature tends to focus on the medieval Muslim or medieval Christian context of reception of Greek dialectic. ${ }^{1}$ For example, existing studies on jadal (Muslim dialectic) discuss among others the origin of jadal and dialectical concepts used in Greek dialectic and jadal literature. Then, they argue either for a distinct Arab-Islamic character of jadal, which is considered free from Greek influence, ${ }^{2}$ or for a heavily Greek character of jadal, ${ }^{3}$ or for parallelism and coincident similarities between Muslim jadal and Greek dialectic. ${ }^{4}$ However, they discuss Greek or Aristotelian dialectic in general, not specifying what kind of Greek or Aristotelian dialectic has such influences or similarities with jadal literature (whether eristic, dialectic, didactic, or peirastic). Furthermore, regarding the search for truth that becomes the central concern of medieval Muslim jadal and Christian scholastic disputation, such studies tend not to elaborate how truth itself is perceived in Greek dialectic, then to undergo a certain alteration and appropriation when taken up by the later traditions.

In short, current studies do not underscore how a shared Greek dialectical root is adopted, appropriated, and modified by medieval Muslim and Christian scholars to address their own problems and to meet their respective needs and aspirations. Therefore, this article aims not only to examine the foundation and goal of Greek dialectical theory but also to elaborate the reception and appropriation of Greek dialectic in both medieval Muslim and Christian contexts. This comparative study will enable us to understand the extent of Muslim and Christian contributions to the development of the dialectical art and their distinctive features as compared to the Greek dialectical root.

\section{Aristotelian Dialectic:}

\section{From Eristic to an Examinational Capacity of Dialectic}

The Socratic method of argumentation in the form of dialogue (question and answer) may provide an important foundation for the development of dialectic. Socratic dialogue, which was famously later perfected by Plato, employs a conversational method in order to reveal logical weaknesses of an opposing argument, expose the ignorance of an opponent, or find the truth. This dialogic method in turn developed into two important modes of 
argumentation, namely rhetoric and dialectic. Inspired by Socratic method, Marcus Tullius Cicero (106-43 BCE) introduced a structure into his theory of rhetoric. For him (according to Novikoff's account), in order to have a sound persuasive argument, the practitioner of rhetoric needs attend the following components: invention, arrangement, style, memory, and delivery. ${ }^{5}$ However, the real shift from Socratic and Platonic dialogue (in the mode of self-reflective conversation) to argumentation between two opposed parties occurred at the hands of Aristotle. Aristotle introduced a practice of debate in which opposing views are contested between two opponents (disputation in utramque partem). He developed this practice in two supplemental books of dialectic that marked his departure from Socratic and Platonic methods of dialogue and dialectic, namely Topics and Sophistical Refutations.

Since the later development of dialectic in both the medieval Christian and Muslim contexts is indebted to the above dialectical works of Aristotle, we need to elaborate the main characteristics and features of Aristotelian dialectic before further discussion on its reception in these contexts. In Topics, Aristotle discusses "dialectic" under the umbrella of "deduction," differentiating dialectical deduction from demonstrative deduction. He defines demonstrative deduction as a deduction from "true and primary" premises and dialectical deduction as the deduction from "what is acceptable" (endoxon). ${ }^{6}$ A similar definition is also given in Sophistical Refutation, where he writes, "Dialectical arguments are those that deduce from reputable premises (endoxa), to the contradictory of a given thesis" (SE 2 165b34). ${ }^{7}$ These two definitions make clear that the main feature of Aristotelian dialectic rests on its premises. In contrast to the premises of demonstration, which have to be "true and primary" and usually operate in philosophical and scientific contexts, the premises of dialectic are endoxa, opinions which are measured by their acceptability and reputability and mainly operate in a dialectical context.

In this regard, Aristotle explains further in Topics 1.10 that the dialectical premises are articulated in the form of questions that have a different degree of acceptability. He says, "A dialectical premise is a question that is acceptable (endoxos) to everyone, or to most people, or to the wise" (104a810 ). When the premises of dialectic are conveyed in the form of a question, it implies that there must be two opposing parties involved in the dialectical argument, the questioner and the answerer. One of them presents an argument in the form of questions and another party answers the ques- 
tions with either an affirmation or a negation. The question in Aristotelian dialectic is not open, that is, but is a restrictive question requiring either acceptance or rejection. ${ }^{8}$ Since the degree of acceptability of the premises helps to determine the success of the dialectical argument, the concession of the answerer to the questioner's premises is important, if not necessary. ${ }^{9}$ The acceptability and reputability of the premises will be stronger if they are accepted by the wise (e.g. philosophers), by a majority of people, or (even stronger) by all people.

Aristotle also elucidates how the art of dialectic along with its endoxa premises applies in a practical setting. At first, there must be a dialectical problem (problema or aporia). This problem is the central issue of the dialectical argumentation. Aristotle defines the dialectical problem as "a point of speculation"10 that can be articulated in the form of a thesis held by an individual, ${ }^{11}$ a sophistical argument constructed by a person, ${ }^{12}$ or a puzzle that needs to be resolved. ${ }^{13}$ However, according to Aristotle, all forms of these dialectical problems can simply be called "theses." ${ }^{14}$

Thesis (sing. of "theses") in a dialectical setting is understood as the belief held by a respondent that contradicts an "opinion held by someone famous for philosophy" or a claim of the respondent that is contrary to the questioner's opinions. ${ }^{15}$ Interestingly, the thesis of the respondent at the same time becomes "a point at which answerer's position may be probed for attack." ${ }^{\prime 6}$ At this point, the questioner finds a right location where he can launch a contra-argument. He equips himself with a series of attacking premises, which are called topos, to refute the answerer's thesis. ${ }^{17}$

While the respondent's thesis is actually a result of a deductive process, the refutation against a thesis is actually a deduction as well, albeit "a deduction to the contradictory." Aristotle writes, "a refutation is a deduction to the contradictory of the given conclusion." ${ }^{18}$ Deduction in this regard should be a valid deduction that derives a sound contradictory conclusion. This cannot be obtained if the deduction does not meet the requirements of valid syllogism. Marko Malink, based on his reading of Sophistical Refutations, comprehensively summarizes requirements of a valid Aristotelian syllogism in the following eight conditions:

First, the conclusion follows necessarily from the premises...Second, the conclusion is not identical with any of the premises...Third, the conclusion follows through the premises...Fourth, the predicate of the refutation's conclusion is the same linguistic expression as the predicate of the opponent's thesis-and likewise for the subject...Fifth, the predicate of 
the refutation's conclusion signifies the same object as the predicate of the opponent's thesis-likewise for the subject...Sixth, the refutation's conclusion and the opponent's thesis affirm and deny the predicate of the subject in the same respect, and relative to same thing, and in the same manner, and at the same time...Seventh, the premises of every deduction are simple predicative questions or simple declarative sentences... Eighth, any deduction can be obtained from a schema of deduction by replacing every occurrence of a given schematic letter by the same linguistic expression. ${ }^{19}$

Based on the above conditions, Aristotle differentiates a refutation that is merely an apparent refutation from a refutation that is considered a genuine one. The apparent refutation may seem to have a valid syllogism but actually contains some fallacies. This kind of refutation fails to meet one or more requirements of valid syllogism. Meanwhile, the genuine refutation is that kind which meets all such conditions, including its sound premises. Although these two types of refutation are each successful in the sense that they can draw a conclusion contradictory to the respondent's thesis, the dialectical refutation, which can expose the inconsistencies, ignorance, or wrong beliefs of the opponent, is the only genuine refutation, since the apparent refutation has its own problems of coherence and consistency.

In this respect, Aristotle formulates thirteen forms of logical fallacies that commonly occur in the context of apparent refutations and deductive arguments. Six of these fallacies are due to language: homonymy, amphiboly/ambiguity, combination/composition, division, accent, and form of expression. The fallacies that are independent of language are seven: accident, consequent, secundum quid, ignoration elenchi, begging the question, non-cause as cause, and many questions. ${ }^{20}$ These fallacies can be exposed by a genuine refutation in the respondent's argument and also can be found in the questioner's apparent refutation.

In addition, as can be seen from the conditions of valid deduction, premises play a crucial role in determining whether a certain deduction is valid or invalid. Unlike the premises of demonstrative deduction, which must be "true and primary," the premises of dialectic deduction are endoxa premises, whose validity is measured by their acceptability and reputability. Based on the kinds of endoxa premises that are used in the refutation, the attitude of the questioner toward those premises, or the purpose of the questioner in using those premises, Aristotle mentions four types of dialectical refutation in SE2 165a38-39. He writes, "Of arguments used in discus- 
sion there are four classes: didactic, dialectic, examinational (peirastic), and contentious (eristic)."

In SE2 165b7-8, Aristotle defines eristic arguments as "those that deduce or appear to deduce to a conclusion from premises that appear to be reputable (endoxa) but are not so." In eristic dialectical refutation, the dialectician may reason syllogistically (or appear to reason syllogistically) from what appears to be endoxa premises to derive a certain conclusion that contradicts the respondent's thesis. However, since the premises are not genuinely reputable and accepted (endoxa), the conclusion drawn from this kind of deduction must be invalid.

For example, if the thesis of the respondent is "It is not possible for a man to give away what he does not have," the dialectician may employ the following apparent endoxa premises and apparent refutation: "(1) A man having ten dice does not have only one. (2) A man having ten dice may give away only one. (3) Therefore, it is possible for a man to give away what he does not have." ${ }^{21}$ This refutation may be successful in terms of having a conclusion that is contradictory to the respondent's thesis. However, there is a problem with the validity and endoxicality (i.e. acceptability and reputability) of its premises, which makes the conclusion problematic as well. The dialectician who utilizes this eristic refutation does not differentiate substance from a relative quality:

For "only" does not signify a particular thing, some quality, or some quantity, but how someone has it relative to something, i.e., that he does not have it with another. ${ }^{22}$

Second, Aristotle explains in SE 2.165b3-4 that dialectical arguments are "those that deduce from reputable premises to the contradictory of a given thesis." In other words, as long as premises of the refutation are endoxa and the conclusion is in opposition to the opponent's thesis, the refutation is dialectical. The minimum requirement of the endoxicality of premises is the acceptance of the opponent, although such acceptance may not be based on his own convictions. ${ }^{23}$ For instance, the respondent holds a thesis that "some robe is not useful." The questioner then refutes this thesis by using the following reasoning: "Every robe is cloak. Every cloak is useful. Therefore, every robe is useful." This is considered both genuine deduction and refutation. ${ }^{24}$

Third, if premises of the refutation are obtained from first principles of a given subject of learning and not from real convictions held by the answerer, Aristotle classifies this kind of refutation as didactic argumenta- 
tion. The teacher plays the role of the questioner in this didactic argumentation while the student functions as the answerer. The premises presented by the teacher, which are first principles of a given science, should be heuristically accepted by the learner regardless of their own convictions. Therefore, in addition to premises that are obtained from principles of a science, one main feature of dialectic in this didactic argumentation is that the thesis which will be refuted is not necessarily rooted in the convictions of the respondent. Aristotle elucidates the concept of didactic arguments in SE2.165b1-3: "Didactic arguments are those that deduce from the principles appropriate to each subject and not from the opinions held by the answerer."

Unfortunately, Aristotle does not provide examples and further explanations about didactic arguments. What we can understand from the above definition of didactic arguments is that these arguments are analogous to peirastic arguments in terms of forms and technics, but also that they differ from them in two regards. First, the didactic argument does not require that the thesis and premises actually reflect the dialectician's real belief, whereas the peirastic argument (the fourth type of argument in Aristotelian dialectic) does. Second, in a didactical setting, the goal of didactic refutation is to attain certain subjects of learning, while in the peirastical context, the aim of the refutation is to show the ignorance of the opponent and to correct his false belief.

Fourth, if premises of the refutation are accepted by the respondent (endoxa) based on his own convictions and are bound to be known by anyone who claims to be an expert, Aristotle categorizes this kind of refutation as peirastic or examinational arguments. He defines such arguments in SE2 165b4-6 as "those that deduce from premises which are accepted by the answerer and which anyone who claims to possess knowledge of the subject is bound to know." In this regard, there are three important components of peirastic arguments: the premises must be conceded by the answerer based on his actual belief, the answerer should have a claim that he is knowledgeable or an expert in the subject being disputed, and the conclusion should be contradictory of the answerer's actual belief.

Aristotle provides an example of an eristic or sophistical argument in order to illustrate how the peirastic refutation might operate and function. He mentions that one may cite an apparent principle in physics or medicine to refute the thesis "it is better to take a walk (than a nap) after dinner." The sophistic argument goes in this order: 
1. Motion is impossible.

2. If motion is impossible then it is not better to take a walk (than a nap) after dinner.

3. Therefore, it is not better to take a walk (than a nap) after dinner.

The first premise is Zeno's thesis, which seems to be in accordance with a principle in physics but in reality is not. The actual accepted principle is "to go a given distance one must first go half way." ${ }^{25}$ Zeno's conclusion, which tweaks and modifies the principle into the premise "motion is impossible", is false. In this situation, the peirastic refutation is able to identify such sophistic (apparent valid) premises, show the invalidity of the argument that is based on it, and eventually reveal the ignorance of the opposing party in the subject at stake. ${ }^{26}$

In addition to the above four types of dialectical refutation, Aristotle also explains five goals that those forms of dialectic aim to achieve. The first goal is merely a refutation; the second is to show that the opponent's argument is false (i.e. demonstrated falsity); the third is to make an opponent say something paradoxical; the fourth is to lead the opponent to agree with inconsistent views (i.e. solecism); and the fifth is to lead the opponent to "babbling," or repeating oneself. ${ }^{27}$ Another goal that Aristotle mentions, especially in the case of refutation by reductio ad impossible, ${ }^{28}$ is to demolish the respondent's premises that are used to derive an impossible conclusion. ${ }^{29}$ All these goals are applied especially in the context of eristic and dialectic, although they may also be occasionally applied in the context of didactic and peirastic refutations. The latter types of argument are supposed to have premises in accordance with a certain subject of science. Furthermore, didactic arguments have educational purposes (learning a subject of science instead of merely exposing a contradiction in the opponent's argument) while peirastic refutations seek to to expose the respondent's ignorance of a subject. ${ }^{30}$ When the respondent claims to be an expert in a given scientific or philosophical subject, peirastic dialectic is able to test (peirastike), examine (exestastike), and expose false claims and the ignorance of the respondent. Aristotle writes in Sophistical Refutations 11.4 171b4-6, "For the art of examining is a branch of dialectic and has in view not the man who has knowledge, but the ignorant pretender (i.e. the one who pretends to know but does not)."

Furthermore, in the context of science and philosophy, Aristotle states in Topics I2 101a36-b4 that peirastic dialectic has an examinational capacity by means of which it provides a way (hodon) to the first principles. His 
account in the Metaphysics gives us a clue as to how dialectic would operate in this way:

Those who wish to be free of aporiai (euporesai) must first go through the aporiai (diaporesai) well; for the subsequent aporiai-free condition (euporia) is reached by untying the knots produced by the aporiai raised in advanced, and it is not possible for someone who is unaware of a knot to untie it. An aporiai in thought, however, reveals a knot in its subject matter. For thought caught in aporiai is like people who don't know where they have to go, and in addition, don't even know whether they have found what they are inquiring about, since the end is not clear to them. But to someone who has first gone through the puzzles it is clear. Besides one is necessary in a better position to discern (krinai) things when one has heard all the competing arguments, like opposing parties in courtroom (Met. B1 995a27-b4). ${ }^{31}$

In this regard, the main task of examinational dialectic is to solve puzzles, or to untie the knots, that hinder a dialectician from reaching first principles. There are two kinds of puzzles that have been recognized by Aristotle's interpreters: those raised by empirical observations of facts and those resulting from logical or philosophical reasoning. ${ }^{32}$ The first kind of puzzle emerges when there is a new empirical finding that challenges an existing scientific theory, which has been claimed to be true. The second appears when there is a sound argument that suspects or finds fallacies and contradictions in an existing widely accepted opinion (endoxa).

It is true that empirical puzzles can only be solved through further empirical observations or inductive reasoning. ${ }^{33}$ That is, peirastic dialectic plays no role in empirical sciences. Yet it can play a significant role in a philosophical and logical context. Peirastic can address philosophical and logical puzzles through further scrutiny of accepted opinions (endoxa) and their propositions by reference to rules of refutation. The examinational capacity of dialectic is not only designed for the purpose of refutation itself (as Robin Smith claims ${ }^{34}$ ) but is also a prelude for finding the first principles.

\section{Medieval Jadal: Praiseworthy Dialectic in Islamic Context}

Arabs and Muslims practiced debate and disagreement centuries before their encounter with Aristotle's dialectical works. They utilized different concepts to refer to this argumentative tradition, such as al-hijä' (satire) and al-naqäid (flytings) in poetry, mujādalah (polemic) in Quranic con- 
text, a genre of khiläf (disagreement) literature as well as jadal (dialectic) in legal and theological scholarship. Pre-Islamic Arab poets were accustomed to composing satirical poems to lampoon their adversaries. Arab-Muslim poets during the Umayyad Dynasty used to write flyting poetry to attack their opponents. Various concepts and forms are used in the Qur'an to refer to religious debates, dialogues, and polemics, including jadal, jidāl, mujädalah, or mujädilah, and their cognates. ${ }^{35}$ In a later period, Muslim jurists and theologians wrote scholarly books that recorded disagreements among scholars or expressed their disagreements towards opposing scholars under the genre of khiläf (disagreement) literature. Then, after the encounter of Muslim scholars with Greek dialectical scholarship, they started to formulate their own theory of jadal (dialectic) in the fourth/eleventh century.

The first encounter of Muslim scholars with Aristotelian dialectical works is through the hands of Muslim theologians (mutakallimūn). After Caliph al-Mahdī (d. 169/785) ordered a translation of Aristotle's book Topics in 165/782, he then asked Muslim theologians to refute arguments of heretics and skeptics by incorporating dialectic (jadal) into their scholarly practices and works. ${ }^{36}$ The main purpose was to defend Islamic faith.

The theologian Yahyyā b. Muhammad b. Isḥāq b. Rīwandī (d. 298/910), better known as Ibn Rīwandī (or Ibn Rāwandī), wrote a treatise on a theoretical jadal entitled $\bar{A} d \bar{a} b$ al-Jadal (The Rules of Debate) at the end of the third/ninth century or the beginning of the fourth/tenth century. Later theological jadal writings emerged with the purpose of either criticizing or defending Ibn Rīwandī, as in the case of al-Ka'bì al-Balkhì (d. 319/931) and al-Ash'arī (d. 319/931). Other jadal theological works focused more on developing jadal theory, which aimed to attain truth, defeat an opponent, or defend certain theological positions from external challenges (i.e. apologetic purposes). The theologians who wrote on jadal include Abū Manșūr al-Māturīdī (d. 332-6/944-8), Ibn Wahb al-Kātib (fl. ca. 335/946), al-Muṭahhar b. Țāhir al-Maqdisī (fl. ca. 355/966), Abū Bakr Muhammad Ibn Furāk (d. 406/1015), Ibn Ḥazm (d. 456/1064), and al-Khātib al-Baghdādì (d. 463/1071). ${ }^{37}$

Although the purpose of their jadal works includes apologetics (i.e. defending the faith and defeating the opponent), the normative claim of these theologians is that they could attain the truth through their work and the practice of jadal. In this respect, Islamic theologians tried to differentiate their dialectic purposes from that of Aristotelian dialectic. If the purpose of Aristotelian dialectic is to show the contradictions of an opponent's rea- 
soning so that one could win a debate, Islamic theologians claim that their purpose through advancing jadal practice and theory is to attain the truth. In order to attain the truth, Muslim theologians modified Aristotelian dialectical questions, namely restrictive "yes" or "no" questions (erotema), into more open questions (pusma) that require a longer reply; and, from logical questions that assess logical validity of an opponent to epistemic questions that seek knowledge and its proofs. ${ }^{38}$

For example, al-Maqdisī formulated a series of dialectical questions to reveal what is considered the truth. According to al-Maqdisī, the four dialectical questions in theology should contain a question about the opinion of the answerer (ma'ìyat al-madhhab), about the evidence (dalil) brought

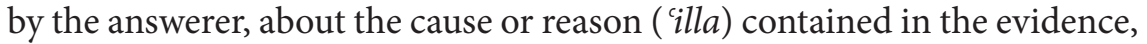
and a question verifying the soundness of the cilla (tașhị al-illah). ${ }^{39}$ The formulation of these questions, in fact, was the first appropriation of Aristotelian dialectic in Islamic scholarship that engendered a more systematized approach to jadal. The Muslim dialectician is then encouraged to build coherent and systematic reasoning to support a claim or argument.

Muslim philosophers, who follow closely Aristotelian dialectic, are critical of theologians for their misinterpretations and for confusing scientific and dialectical questions. For the former, questions about the nature of an opinion, evidence, or causes ( $i$ illah) used by theologians are essentially not dialectical questions but scientific questions. Dialectical questions, the philosophers argued, are those questions that start from accepted premises (endoxa) and aim to make the opponent fall into an inconsistent argument. Therefore, Ibn Sīnā (d. 428/1037), a leading Muslim philosopher, defines jadal in the Aristotelian sense. He states that jadal is "an art which enables us to prove a thesis by an argument proceeding from generally accepted premises, and when answering we do not give anything contradicting our thesis." ${ }^{40}$ Logical consistency and coherence are considered dialectical truth; therefore, if the opponent makes an incoherent or inconsistent statement, it means that he/she is defeated. Muslim theologians, according to philosophers, do not understand this concept correctly. ${ }^{41}$ They apply scientific questions with an intention of finding a "scientific truth," which means a sound conclusion derived from a proper induction, deduction, or demonstration, to defeat their opponents. ${ }^{42}$ For philosophers, this is impossible since dialectic and scientific premises are different, and therefore cannot produce the same "truth." The premises of dialectic are endoxa premises whose validity is viewed from their acceptability and reputability, whereas 
the premises of science are "true and primary" premises whose validity is assessed from first principles of a given science.

In this regard, Muslim legal theorists want to demonstrate that attaining "scientific truth" through the series of questions utilized by theologians is possible, namely through so-called "praiseworthy jadal." One of the leading legal theorists, Abū Bakr Muhammad b. 'Alī b. Ismā'îl al-Qaffāl alShāshī (d. 365/976), started to differentiate between "praiseworthy jadal" and "reprehensible jadal." ${ }^{43}$ The former is associated with the spirit of finding the truth whereas the latter is linked with the purpose of only winning the debate or defeating the opponent. ${ }^{44}$ The legal theorists would regard the jadal of theologians and of philosophers as "reprehensible jadal," since it is designed only to defeat their opponents by making them to say something contradictory or inconsistent (something to which these legal theorists would impute the desire for personal fame or even wealth). In turn, they attempt to demonstrate that arriving at the truth through the practice of jadal is possible so long as a dialectician employs "praisworthy jadal" with its correct rules and procedures.

After the name of al-Qaffāl al-Shāshī (d. 365/976) was linked with the initial development of "praiseworthy dialectic", some other jadal works were written. Abū 'Abd Allāh al-Ḥusayn b. 'Alī al-Șaymirī (d. 436/1044) wrote Masāil al-Khilāf fì ușūl al-fiqh. Ibn Hazm (d. 456/1063) published his jadal work entitled al-Taqrīb li hadd al-mantiq wa al-madkhal ilayhi bi al-alfāz al-'āmmìyah wa al-amthilah al-fiqhīyah. Abū al-Walīd al-Bājī (d. 474/1081) systematized dialectical practices in al-Minhāj fì tartīb al-hijāj. Abū Bakr al-Khaffāf (circa $4^{\text {th }} / 10^{\text {th }}$ century) wrote al-Aqsām wa al-Khișāl, which among other things discussed the order of questions and ethics in jadal setting. ${ }^{45}$ According to Miller, the early period of jadal theory in legal tradition started when Abū Ishāa al-Shīrāzì (d. 476/1083) wrote a book entitled al-Ma'ūnah fī al-jadal. ${ }^{46}$ His student, Abū al-Wafā' b. 'Aqīl (d. 513/1119), also followed in his footsteps by writing a jadal book entitled Kitāb al-jadal 'alà țariqat al-fuqahà'. The development of jadal theory in this period reached its culmination, according to Hallaq, at the hands of Imam al-Haramayn al-Juwaynī (d. 478/1085). ${ }^{47}$

However, Imam al-Haramayn al-Juwaynī was not only a jurist (faqīh), as Miller and Hallaq classify his scholarship. He was in fact also a theologian (mutakallim) who wrote influential theological treatises such as Kitāb al-Irshā $d^{48}$ and al-Shāmil fì ușūl al-dīn. ${ }^{49}$ He followed the Shāfíi school in fiqh (law) and the Ash'arī school in kalām (theology). He formulated a 
full-systemized dialectical theory in al-Käfìyah $f \bar{i}$ al-jadal, which was then also applied in his kaläm and fiqh works. In this regard, as a jurist and theologian, Imam al-Haramayn employed "praiseworthy jadal" (al-jadal al-mahmu $\bar{d}$ ) in both legal and theological settings, not in legal discourse alone.

He defined jadal (in both juridical and theological discourses) as " jadal that aims to find truth and discloses falsehood, aspires to obtain a divine guidance, along with those who want to return to the truth from the falsehood." ${ }^{0}$ The truth, according to Imam al-Haramayn, is al-thubüt (fixedness or certainty). ${ }^{51} \mathrm{He}$ explains that the meaning of truth (in this sense) can differ: as pertaining to a report (khabr), truth means "truthful or reliable" (sidq). It means "the commanded act" if the word is used in relation to religious laws, and means "correctness" (șawāb) and "soundness" (sihhaha) in various contexts. If the term "truth" is utilized in relation to a legal qualification, command, creation, or an attribute of the divine attributes, it means "God the Exalted." ${ }^{2}$ In a principle, the term "truth" (bearing the meaning of al-thubut t) is always used in a positive sense, not in a pejorative one. For example, Imam al-Haramayn clarified, one cannot say "Injustice is truth," because the term "truth" here is attached to a pejorative term. ${ }^{53}$ In turn, the attempt to search for the truth (with the meaning of "certainty" or "fixedness") is not only limited to dialectic (jadal) in the study of Islamic legal tradition (al-sharīah) but also in the study of theology (al-tawhìd). ${ }^{54}$

In general, the truth (as al-thubutt) in both law and theology is attainable through univocal texts (nușuss) of religious scriptures, writes Imam al-Haramayn. In this regard, the level of al-thubüt reaches the degree of epistemological certainty (qat $\bar{i} \bar{l}$ ) or the level of psychological certainty (al-yaqin). However, the level of al-thubüt in matters that are not addressed univocally by religious texts is not as high as the previous ones. Rather, they need scholarly discretion (ijtihād) either through regular deductive reasoning (istidlāl) or through dialectic (jadal). The level of al-thubüt resulting from istidlāl is probable (zannī), while that from the jadal process is "preponderant conviction" (ghalabat al-zann), which yields psychological certainty (yaqin). ${ }^{55}$

\section{Medieval Scholastic Disputation: Searching for the Truth in Medieval Europe}

Alex J. Novikoff and Olga Wieijers elucidate how scholars and religious figures developed their own tradition of debate and dialogue that became 
rudimentary forms of dialectical tradition in the medieval Western context. Novikoff explains that Augustine, who refuted Manichean doctrines through public disputations and inner dialogical reflection, laid a strong foundation for the tradition of dialectic in the medieval monastic world. Especially through his early book Soliloquia, Augustine introduced a form of meditative and contemplative inner dialogue for seeking the truth to his late antique audience. This method, soliloquia, literally means "talking to ourselves alone." ${ }^{56}$

The later scholar who inherited Augustine's meditative method, Novikoff writes, was Anicius Manlius Boethius (481-524). In his masterpiece, Consolatio Philosophiae, he used Augustine's "inner dialogue" in addition to incorporating the literary forms of other philosophers, including Cicero, the Stoics, and the Neoplatonists. The contribution of Boethius to dialectical scholarship extended to his works of translation, including of Aristotle's categories and De interpretatione. Boethius marked a first wave of such translation and became a bridge between late antiquity and the early medieval development of the art of disputation. ${ }^{57}$

The pre-Aristotelian form of disputation in medieval Europe continued to thrive, especially with the revival of pedagogical dialogue and dialectic during the Carolingian Renaissance in the eighth and ninth century. Even Charlemagne (768-814) used dialogue and dialectic in his court sessions. In the eleventh century, Peter Damian (1007-1072) harnessed a method of disputation to argue against Jews and to promote a reform in the Church. Lanfranc of Pavia (1005-1089) too employed dialogue and disputation in the classroom, allowing a student like Anselm of Bec (1033-1109) to master these arts in pedagogy, philosophy, and theology. Anselm used the Socratic debate with his students, incorporated disputation into his intellectual methodology and philosophy, disputed with pagans, heretics, and Jews using dialectic, and employed rational investigation and dialectical argumentation to arrive at Christian truth. ${ }^{58}$

In the twelfth century, with the emergence of monastic schools, cathedral schools, and private schools, the art of dialogue and dialectic became even more important. Novikoff reports that the works of Plato and Aristotle in dialectic were generally not translated and were only known through secondary sources, ${ }^{59}$ but the method of dialectic (as part of the trivium, alongside rhetoric and grammar) was already incorporated in the curriculum of those schools, especially for the study of theology. The most notable figure in the early twelfth century was Peter Abelard (1079-1142), 
who in his Collationes invoked Augustine but also Aristotle, referring to the (still unavailable) Sophistical Refutations through a second-hand source. He furthermore started to differentiate between dialectic, which is considered truth-oriented, and sophistry, which is considered oriented toward an apparent truth..$^{60}$ In his account, however, Novikoff does not mention how Abelard and other medieval European scholars accessed the Aristotelian dialectical tradition, considering that the original Greek texts were then unavailable in the West.

In this regard, George Makdisi and Christopher Beckwith provide an important observation of how the dialectical argument was transmitted from Greek sources through Arabic texts and scholarly practices to Latin audiences in Europe. Makdisi mentions a scholar named Photius whose book, Amphilochia (Quaestiones Amphilochianae), contains a collection of questions and answers on various religious and philosophical issues and formulates foundational rules of how to reconcile apparent contradictions in religious scriptures, which later Peter Abelard (1079-1142) and other scholars used in their works. ${ }^{61}$ According to Makdisi, Photius served as ambassador to the court of an Abbasid caliph, al-Mutawakkil, in 855, when he was 35 years old. He most likely encountered the khiläf (disputation) tradition at that court; indeed, as a reputable scholar, Photius might well have been invited to participate in that disputation. ${ }^{62}$ In turn, through Photius, the practice and literature of disputation-including the Aristotelian forms that had then been translated into Arabic-reached European audiences.

Another possible mode of the transmission of dialectic is through the translation movement from Arabic to Latin in Toledo, Spain. After al-Andalus was conquered by Alphonse VI in 1085, Toledo became "the most important center of translation from Arabic to Latin, under the patronage of Archbishop Raymond (1126-1153)." ${ }^{63}$ Two important translators in Toledo at that time were Constantine the African (d.c. 1087) and Adelard of Bath (d. after 1142), who were contemporaries of Peter Abelard. ${ }^{64}$ However, according to Beckwith, the first Arabic book using Aristotelian dialectical method that appeared in Western Europe was Ibn Sinnās work, De Anima, which was translated from a chapter on al-Nafs (the Soul) from his Kitāb al-Shifä' (The Book of Healing). The project of translating Ibn Sīnäs work into Latin, especially his discussions of Aristotelian dialectic, was carried out by two translators from Toledo, the Jewish philosopher Avendauth (ibn Dảūd) and Dominicus the Archdeacon. They presented their translation 
works to Archbishop John of Toledo (r. 1152-1166), the successor of Archbishop Raymond who initiated the translation movement. ${ }^{65}$

There are thus two possible routes of the transmission of Aristotelian dialectic from Arab-Muslim scholarship to Latin Europe. It may have occurred through oral disputations witnessed and practiced by Europeans like Photius in their contact with Arab-Muslim scholars. Or it may have happened through a direct translation of Aristotle's dialectical works (along with Arabic commentaries) from Arabic into Latin in Toledo. The most obvious evidence of transmission via translation was the twelfth-century Latin rendition of Ibn Sīnās De Anima. The book contains recursive or dialectical arguments that involved two opposing parties, using the model of Aristotelian dialectic. ${ }^{66}$

Novikoff seems to overlook the role of such Arabic sources in the transmission of Greek knowledge into Latin scholarship. He only lists a series of translations of Aristotle's works, starting from the first wave of translation in the time of Boethius in the sixth century to the second wave of translation in the twelfth century and the third wave of translation in the late fifteenth century. ${ }^{67}$ This account implies that there is nothing happening between these waves, between the sixth century and twelfth century. In fact, as described above, that is the period when the majority of Aristotle's works was translated into Arabic and medieval European scholars engaged the Arabic intellectual tradition either through direct contacts or through Arabic translations of Greek texts.

The first serious, first-hand encounter of European scholars with Aristotle's works took place in the second half of the twelfth century. These scholars received them in various forms, either through glossed manuscripts, university documents, surviving commentaries, or actual copies of Aristotle's texts. ${ }^{68}$ The direct encounter and interaction with the Aristotelian dialectic shaped the scholastic practice of disputation in the twelfth and thirteenth centuries. The early witness of Aristotle's new logic was Adam of Balsham, who discussed Aristotelian fallacies, while the most comprehensive and engaging discussion of Aristotelian dialectical works was conducted by a student of Peter Abelard, named John of Salisbury (d. 1180).

John of Salisbury defended the use of the trivium (grammar, rhetoric, and dialectic) in his masterpiece, Metalogicon. Furthermore, he showed the importance of Aristotle's newly translated dialectical works, namely Topics and Sophistical Refutations, and utilized it to argue against his opponents, such as the pseudonymous Cornificius and his fellows. The recovery of 
Aristotele's dialectical works marked, in Novikoff's terms, "a significant moment of formative development of scholastic dialectic," ${ }^{69}$ as became apparent in the thirteenth century. Novikoff notes how in this period the art of disputation entered the university curriculum and monastic orders. The fully developed scholastic disputation emerged and was practiced in universities and mendicant learning institutions, especially within Dominican orders. In their universities, students and teachers employed two forms of disputation: the disputatio ordinaria, which is an ordinary disputation held in the morning in a certain subject of learning for the benefit of bachelors and students; and the disputatio de quolibet, which is a disputation of any subject and discipline held for the benefit of students and faculty members. Meanwhile, in the Dominican order, the art of disputation was able to push boundaries of speculative thought and to shape cultural practices of the order. One of the most influential Dominican scholars was Thomas Aquinas, who used the dialectical method in his Summa Theologiae. He also categorized disputation into ordinary disputation, which aims to remove doubt and logical errors, and disputatio marginalis in scholis, which aims for understanding the truth that a master has in mind. ${ }^{70}$

In the golden period of European disputation, namely the thirteenth and fourteenth centuries, the art of dialectic became a method of teaching, training, and research in European universities. Among other forms of dialectic, two were typically practiced in the university settings. The first type of dialectic is eristic disputation, which functions as an intellectual exercise for students and is usually applied in the study of grammar and logic. This form of dialectic develops into a more refined genre called ars obligatoria or obligationes. In obligationes, Olga Weijers writes, "the opponent tries to lead the respondent to accept propositions that are contrary to the thesis the respondent has 'obliged' himself to defend." ${ }^{71}$

The second type of dialectic is the scholastic disputation, which usually takes place in a university setting between students and a teacher. There are three participants in this form: the teacher, the respondent, and the opponent. First, the teacher will pose a question that should be answered in an affirmative or negative way. Then the respondent gives a preliminary answer to this question. If his answer is affirmative, the opponent will attack the respondent's answer while at the same time making an argument or defending the negative answer. Similarly, if the respondent's answer is negative, the opponent will attack the respondent's argument and defend the opposing view. In the end, the teacher will provide the solution (i.e. 
the right answer to the question) and discard the wrong answer. Unlike the eristic disputation, which generally arises not from a textual reading, the scholastic disputation is usually triggered by a conflicting interpretation of texts, especially in the faculty of arts and theology. Then, the teacher and students will hold a disputation and evaluate which of two possible interpretations is right. In the end, the goal of scholastic disputation is to arrive at the truth, to teach the truth, or to find the right answer to the question posed by the teacher. ${ }^{72}$

\section{Conclusion}

Medieval Muslims and European Christians had their own culture of debate and disputation prior to the arrival of Greek philosophical treatises in their respective lands. The medieval Muslim scholars had genres of satirical (al-hijä) and critical (al-naqä’ị) poetry, khiläf (disagreement) practices and literature in law and theology, as well as mujädalah (polemic), munāzarah (disputation), and jadal (dialectic) in the Quranic and scholastic context. Meanwhile, medieval European Christian scholars practiced reflective or meditative dialogue since the time of Augustine and Boethius in the fifth-sixth century.

However, Muslim and Christian encounters and interaction with Aristotle's treatises on dialectic brought a new dimension to their respective cultures of debate and disputation. In Aristotle's concept, the main purpose is not to find the truth in a scientific sense, which is the truth derived from "true and primary" premises through a process of induction or deductive-demonstrative reasoning. Dialectic, whose premises are endoxa (i.e. determined by its reputability and acceptability), can be used to serve different objectives. It can be used for the sake of refutation itself. It can be employed to defeat opponents by exposing the weaknesses of their argument, or forcing them to say something paradoxical, inconsistent, or self-repeating. It can also be utilized to destroy opponents' premises so that they will draw an impossible conclusion from such premises. Two kinds of dialectic (namely didactic and peirastic dialectic) seek more than a mere refutation and winning debate. The former is used to learn a certain science or subject through a dialectical process while the latter is used to examine the opponents' argument in order to show their ignorance in a given subject or to remove "scientific" puzzles so that one can arrive at first principles of a given science. 
When Aristotle's concept of the dialectic reached Muslim lands through translation, medieval Muslim scholars, who had their own problems to address (such as legal and theological uncertainties that convened sectarian conflicts), adopted modified elements of the Aristotelian dialectic in order to solve those problems. The legal theoretical scholars (ușūìy ùn), for example, would not use the eristic type of Aristotle's dialectic in their works and practices because it would not help them to solve legal problems. Instead, they harnessed the examinational capacity of Aristotelian peirastic dialectic in order to achieve a certain level of credibility and certainty in religious knowledge (either in the form of ilm or ghalabat al-zann). They examined their opponents' arguments through a series of dialectical questions that were different from that of Aristotle.

Meanwhile, after being exposed to Aristotle's theory of dialectic through Arabic (secondary) sources, then through Greek (original) texts, medieval European scholars also adopted some elements of Aristotelian dialectic in their scholarly practices and work. While the eristic dialectic might be used for religious debates against internal opponents ("heretical" Christians) and external adversaries (mainly Jews), the main dialectic that was practiced in a scholarly setting is the didactic type. Therefore, when the medieval scholastic disputation aimed to find "the truth" through dialectical practices, "the truth" here is not related to showing the ignorance of the opponent in a certain subject (like Aristotelian peirastic dialectic) or to arrive at a certain level of certainty (like medieval jadal). The truth in the context of the medieval scholastic disputation was finding the correct answer from questions posed by a teacher in order to learn a certain subject.

In other words, although Greek dialectic has an influence over both medieval Muslim and Christian scholarship, each of them employs and modifies Aristotelian dialectic in order to serve their own purposes. Medieval Muslim scholars practiced a "praiseworthy dialectic" (al-jadal al$m a h m \bar{u} d$ ) that was not directed at defeating opposing parties rhetorically with the aim of gaining fame, wealth, or prestige. Compared to Aristotelian dialectic, Imam al-Haramayn's jadal (as surveyed above) is also more analogous and closer to the peirastic form than to eristic, regular, or didactic forms: his jadal is believed capable of leading someone to obtain certainty in juridical and theological realms. Meanwhile, medieval Christian scholars named their dialectical practices "the scholastic disputation," which was designed to study a certain subject of learning through finding the correct answer, as stored in the mind of the teacher. 


\section{Endnotes}

1. The reception of dialectic in medieval Christian scholarship is discussed by Alex J. Novikoff, The Medieval Culture of Disputation: Pedagogy, Practice, and Performance (Philadelphia: University of Pennsylvania Press, 2013) and Olga Wieijers, In Search of the Truth: A History of Disputation Techniques from Antiquity to Early Modern Times (Belgium: Brepols, 2013). For the reception of dialectic in medieval Muslim scholarship, see Larry B. Miller, "Islamic Disputation Theory: A Study of the Development of Dialectic in Islam from the Tenth through Fourteenth Centuries" (PhD diss., Princeton University, 1984) and Mehmet Kadri Karabela, "The Development of Dialectic and Argumentation Theory in Post-Classical Islamic Intellectual History" (PhD diss., McGill University, 2010).

2. See Muhammad Abū Zahrah, Tārīkh al-Jadal (Egypt: Dār al-Fikr al-'Arabī, 1980); Barakāt Muhammad Murād, Manhaj al-Jadal wa al-Munāzarah fī alFikr al-Islāmī (Cairo: al-Ṣadr li Khidmāt al-Ṭibā'ah, 1990).

3. See Josef van Ess, "The Logical Structure of Islamic Theology" in Logic in Islamic Culture, ed. Gustave E. von Grunebaum (Germany: Otto Harrassowitz, 1970).

4. See Walter Edward Young, “The Dialectical Forge Part I: Proto-System Ju। ridical Disputation in the Kitāb Ikhtilāf al-Irāqiyyīn" (PhD diss., McGill University, 2012); Miller, "Islamic Disputation Theory."

5. Novikoff, The Medieval Culture of Disputation, 12.

6. See Topics, 100a27-31 in Aristotle, Topics Book I and VIII, trans. Robin Smith (Oxford: Oxford University Press, 1997), 1.

7. Aristotle, "Sophistical Refutation," in Aristotle: The Complete Works (Virginia: Intelex Past Masters Corporation, 1992).

8. Aristotle, Topics Book I and VIII, 45.

9. Ibid.

10. Topics I.11, 104b1-6.

11. In Topics I.11, 104b30-36, Aristotle writes, "A thesis, then, is also a problem, but not every problem is a thesis, since some problems are the sort of thing about which we think nothing either way. But that a thesis is problem is clear. For it is necessary from what has been said either the public disagrees with the wise about the position, or that one or the other group disagrees among themselves, since a thesis is some belief contrary to opinion."

12. "The sophistical argument (against incontinence) is an aporia. For because they want to refute (elengchein) people in contradoxical ways, so that they will be clever in ordinary discussions (epituchôsin), the deduction they construct gives rise to an aporia; for thought is tied up in knot, since it does not want to stand still because it dislikes the conclusion, but it cannot move forward because it cannot undo the argument" (NE VII.2 1146a21-7). 
13. "As in other cases, we must set out the appearances; first of all go through the puzzles. In this way, we must prove the common beliefs about these ways of being affected-ideally, all the common beliefs, but if not all, most of them and the most compelling. For if the objections are solved, the common beliefs are left, it will be an adequate proof" (NE, VII.1, 1145b2-7).

14. He writes, "In practice, all dialectical problems probably called theses. But let make no difference whatever it is called." See Topics I.11, 104b35-37.

15. Topics I.11, 104b19-25.

16. This is sometimes called topos, but I reserve the term topos for another meaning, which is a series of premises that are used to attack the opponent's thesis. See R. Smith, "Introduction," in Aristotle, Topics Book I and VIII, xxvii.

17. In Smith's interpretation, the term topos is also used to denote "a location under which a large number of arguments can be stored for ready recall." It means that in addition to the meaning of topos as "a point of attack in adversary's position," it also refers to "a location under which to file arguments," which contains a list of premises than be used to launch an argument against the respondent's thesis. See ibid., xxviii.

18. SE6, 165a3-4.

19. Marko Malink, "Deduction in Sophistici Elenchi 6", in Strategies of Argument: Essays in Ancient Ethics, Epistemology, and Logic, ed. Mi-Kyoung Lee (New York: Oxford University Press, 2014), 149-174.

20. Aristotle, Sophistical Refutations 4 165b23-166b27.

21. See SE22 78a29-31.

22. See the reading and the translation of Aristotle's explanation of fallacies in refutation in Scott G. Schreiber, Aristotle on False Reasoning: Language and the World in the Sophistical Refutations (Albany: State University of New York Press, 2003), 40.

23. Robert Bolton, "The Aristotelian Elenchus," in The Development of Dialectic from Plato to Aristotle, ed. Jakob L. Fink (Cambridge: Cambridge University Press, 2012), 273.

24. Malink, "Deduction in Sophistici Elenchi 6," 162.

25. See Aristotle, Physics 8.8.263a4ff.

26. See the discussion of this example in Bolton, "The Aristotelian Elenchus," 286-287.

27. He writes in SE3 165b13-22: "First we must grasp the number of aims entertained by those who argue as competitors and rivals. These are five numbers: refutation, falsity, paradox, solecism, and fifthly to reduce the opponent in the discussion to babbling (i.e. to constrain him to repeat himself a number of times); or it is to produce the appearance of each of these things without the reality. For they choose if possible plainly to refute the other party, or the second best to show that he is saying something false, or as a third best to lead him into paradox, or fourthly to reduce him into solecism, i.e. to make 
the answerer, in consequence of the argument, use some barbarous mode of expression; or, as a last resort, to make him repeat himself."

28. Aristotle explains that reductio ad impossible occurs when the argument considers "what is not a cause" as a cause and is inserted into an argument, as though a conclusion is derived from such "not a cause" premise. See SE5.167b21-25. Bolton, a prominent Aristotelian scholar, interprets that this reductio ad impossible argument happens in the context "where the opponent's thesis is taken as one of the premises of the purported refutation and from it, together with other premises, a conclusion which is impossible is deduced with the result that the opponent's thesis is destroyed." See Bolton, “The Aristotelian Elenchus," 277.

29. Aristotle SE5.167b23-25 states, “This kind of thing happens in deductions ad impossible; for in these we are bound to demolish one of the premises."

30. See Bolton, “The Aristotelian Elenchus," 281.

31. This passage as translated by Carrie E. Swanson, an Assistant Professor at Department of Philosophy, University of Iowa.

32. T.H Irwin, "Ways to First Principles: Aristotle's Method of Discovery," Philosophical Topics 15, no. 2 (Fall 1987): 123-124.

33. Ibid.

34. Robin Smith, "Dialectic and Method in Aristotle," in From Puzzles to Principles, Essay on Aristotle's Dialectic, ed. May Sim (Oxford: Lexington Books, 1999), 52.

35. See Abdulla El Tayeb, "Pre-Islamic Poetry," in Arabic Literature to the End of the Umayyad Period, ed. A.F.L Beeston, T.M. Johnstone, R.B. Serjeant, and G.R. Smith (Cambridge: Cambridge University Press, 1983); Hussain Abulfaraj, "Umayyad Poetry as Verbal Duel” (PhD diss., Indiana University-Bloomington, 2012); Rosalind Ward Gwynne, Logic, Rethoric, and Legal Reasoning in the the Qur'ān: God's Argument (London: Routledge, 2004); Young, "The Dialectical Forge."

36. See Abū al-Hasan al-Mas'ūdī, Murūj al-Dhahab wa Ma'ādin al-Jawhar, ed. Charles Pellat (Beirut: Manshūrāt al-Jāmicah al-Lubnānīyah, 1974), 5:212. This is different from the claim made by Christopher I. Beckwith who argues that the first Muslim scholar using a dialectical method in the scholarship is Ibn Sīnā (370/980-428/1037). He argues that Ibn Sinnā learns and inherits the dialectical tradition from people and teachers in madrasas in Central Asia who converted from Buddhism to Islam. See Beckwith, Warriors of the Cloisters: The Central Asian Origins of Science in the Medieval World (Princeton: Princeton University Press, 2012), 87-94.

37. Young, "The Dialectical Forge," 22; Miller, "Islamic Disputation Theory," 5-8.

38. Miller, "Islamic Disputation Theory," 24.

39. Ibid., 15-16. 
40. Ibn Sīnā, al-Shifầ: al-Mantiq, ed. Aḥmad Fu'ād al-Ahwānī (Cairo: al-Hay’ah al-'Āmmah li Shu'ūn al-Mațabi' al-Amīrīyah, 1965), 6:21.

41. Miller, "Islamic Disputation Theory", 31-32.

42. See Miller's discussion of philosophers' possible critiques of theological jadal in ibid., 24-26 and 31-32.

43. Wael B. Hallaq, A History of Islamic Legal Theories: An Introduction to Sunnī Ușūl Al-Fiqh (Cambridge: Cambridge University Press, 1997), 136.

44. Karabela, "The Development and Dialectic and Argumentation Theory," 124.

45. Cf. the edition of al-Khaffāf's work in Ahmed Elshamsy's discussion of "Bridging the Gap: Two Early Texts of Islamic Legal Theory," Journal of the American Oriental Society 137, no. 3 (July-Sept 2017): 505-536, which belong to Ibn Surayj and Abū Bakr al-Khaffāf. See Anna-Karina Hermkens and Jaap Timmer, "Conflicting States: Violent Politics in North Maluku, Indonesia," Etnofoor 23 no. 2 (2011): 532-536.

46. Miller, "Islamic Disputation Theory," 88-89. Other periods of jadal theory that Miller discusses are a "middle period," which includes jurists such as Abū Yusr Muhammad al-Pazdawī (Hanafī, d. 482/1089) and Rukn al-Dīn al'Amīdī (Hanafī, 615/1218), and a "final period," which starts to incorporate Aristotelian logic in the hands of scholars such as Burhān al-Dīn al-Nasafī (Hanafì, d. 686/1288) and Shams al-Dīn al-Samarqandī (d. 702/1302). See ibid., 142-195.

47. Hallaq, History of Islamic Legal Theories, 136.

48. Imam al-Haramayn al-Juwaynī, Kitāb al-Irshād, ed. Muhammad Yūsuf and 'Alī 'Abd al-Mun'im 'Abd al-Hamīd Mūsa (Egypt: Maṭba'a al-Sa'āda, 1950).

49. Imam al-Haramayn al-Juwaynī, al-Shāmil fì Ușūl al-Dīn, ed. Helmut Kloepfer (Cairo: Dār al-'Arab).

50. Imam al-Haramayn al-Juwaynī, al-Käfìya fì al-Jadal, ed. Fawqìyah Husayn Mahmūd (Cairo: Dār al-Ihyā' al-Kutub al-'Arabīya, 1979), 23.

51. Ibid., 43.

52. Ibid., 43-44.

53. Ibid., 44.

54. Ibid., 24.

55. Ibid., 32. See also the discussion of the relationship between jadal and yaqin in the introduction written by Mahmūd F. Husayn in al-Juwaynī, al-Käfiyya fì al-jadal, 26-30.

56. Novikoff, The Medieval Culture of Disputation, 23.

57. Ibid., 22-26.

58. Ibid., 33-61.

59. Ibid., 67-68 and 87.

60. Ibid., 87 . 
61. George Makdisi, The Rise of Colleges (Edinburgh: Edinburgh University Press, 1981), 259.

62. Ibid.

63. Ibid., 260.

64 Ibid.

65. Beckwith, Warriors of the Cloisters, 100.

66 See ibid., 118.

67. Novikoff, The Medieval Culture of Disputation, 106-107.

68. Ibid., 107. Most probably, the surviving commentaries are written in Arabic, since the medieval European scholars received Aristotle's original mainly from their Arabic counterparts.

69. Ibid., 113.

70. Ibid., 165-166.

71. Wieijers, In Search of the Truth, 149.

72. Ibid., 122. 